\title{
ANALISIS BUKU SISWA "SEJARAH KEBUDAYAAN ISLAM" KELAS VII MADRASAH TSANAWIYAH KURIKULUM 2013
}

\author{
Irinne Fauz Yusria \\ Universitas Muhammadiyah Malang \\ irinnefauz@gmail.com
}

\begin{abstract}
In the implementation of Curriculum 2013, a book teaching or book student can be used as a source of learning. Books students are prepared to facilitate the participant students in understanding the material that is delivered and becomes the handle of students in the process of learning. The research is aimed to find out the things what only the must be considered in analyzing a book, so the reader can determine the model of books students like that worthy used both in the perspective of education as well as the perspective of psychology. The analysis of the book is, the expected party who is concerned can make this as a matter of evaluation for publication the next. The method that is used in research this is a library research or research literature. The data obtained is of a source of primary, among other books students History of Culture Islam MTs Class VII, thesis, theses, and reports of research. While the source of the secondary are journals, articles, textbooks, and sources other related. The results of the research of this is there are several aspects that must be considered in analyzing the book, among others relevance with the curriculum, the clarity of the concept, the content of the material, illustration, aspects of language, ibrah, as well as the time allocation. From the contents are, there is some content that can be connected with the theory of psychology. The books of Islamic Culture History VII grade students with 2013 Curriculum are as follows: 1) Relevance with the curriculum, KI and KD compiled are relevant to the 2013 curriculum because they are in accordance with Permenag No. 912 in 2013, 2) The clarity of the concept of the book SKI MTs Class VII Curriculum 2013 is already quite clear and easy to understand by presenting a map of concepts in every beginning of the chapter, 3) Fill material if in terms of in terms of psychology, the depth and breadth of the material is already in accordance with age participants learners, 4) illustrations, for the presentation of illustrations if the review of the terms of the psychology still less precise in the placement and still there are some images that are less appropriate to the theme, such as cover, 5) Aspects of linguistic, the language that is used in the book is pretty straightforward, effective, communicative, dialogical and interactive, 6) ibrah in the book of this can be seen in the column "Mutiara Hikmah" on each chapter, and it is very facilitate reader, 7) Allocation of time has been appropriate and sufficient for a period of two semesters.
\end{abstract}

Keywords: Analysis of student books, 2013 curriculum, history of Islamic culture

\begin{abstract}
Abstrak : Dalam penerapan Kurikulum 2013, buku ajar atau buku siswa dapat digunakan sebagai sumber belajar. Buku siswa disusun untuk mempermudah peserta didik dalam memahami materi yang disampaikan serta menjadi pegangan siswa dalam proses pembelajaran. Penelitian ini bertujuan untuk mengetahui hal-hal apa saja yang harus diperhatikan dalam menganalisis sebuah buku, sehingga pembaca dapat mengetahui model buku siswa seperti yang layak digunakan baik dalam perspektif pendidikan maupun perspektif psikologi. Dengan adanya analisis buku ini, diharapkan pihak yang bersangkutan dapat menjadikan ini sebagai bahan
\end{abstract}

PALAPA : Jurnal Studi Keislaman dan Ilmu Pendidikan

Volume 8, Nomor 2, November 2020; p-ISSN 2338-2325; e-ISSN 2540-9697; 196-209

https:/ / ejournal.stitpn.ac.id/index.php/palapa 
evaluasi untuk terbitan selanjutnya. Metode yang digunakan dalam penelitian ini adalah library research atau penelitian kepustakaan. Data yang diperoleh merupakan dari sumber primer, antara lain buku siswa Sejarah Kebudayaan Islam MTs Kelas VII, skripsi, tesis, dan laporan penelitian. Sedangkan sumber sekundernya adalah jurnal, artikel, textbooks, serta sumber lain yang berkaitan. Hasil dari penelitian ini adalah ada beberapa aspek yang harus diperhatikan dalam menganalisis buku, antara lain kerelevansian dengan kurikukulum, kejelasan konsep, isi materi, ilustrasi, aspek kebahasaan, ibrah, serta alokasi waktu. Dari konten-konten tersebut, ada beberapa konten yang dapat dihubungkan dengan teori psikologi. Buku siswa Sejarah Kebudayaan Islam kelas VII MTs dengan Kurikulum 2013, sebagai berikut: 1) Kerelevansian dengan kurikulum, KI dan KD yang disusun sudah relavan dengan kurikulum 2013 karena sudah sesuai dengan Permenag No. 912 tahun 2013. 2) Kejelasan konsep pada buku SKI Kelas VII MTs Kurikulum 2013 ini sudah cukup jelas dan mudah dipahami dengan menyajikan peta konsep di setiap permulaan bab, 3) Isi materi jika ditinjau dari segi psikologi, kedalaman dan keluasan materi sudah sesuai dengan usia peserta didik, 4) Ilustrasi, untuk penyajian ilustrasi jika ditinjau dari segi psikologi masih kurang tepat dalam penempatannya dan masih ada beberapa gambar yang kurang sesuai dengan tema, seperti cover, 5) Aspek Kebahasaan, bahasa yang digunakan pada buku ini cukup lugas, efektif, komunikatif, dialogis, dan interaktif, 6) Ibrah pada buku ini dapat dilihat pada kolom "Mutiara Hikmah" pada setiap bab, dan itu sangat memudahkan pembaca, 7) Alokasi waktu sudah sesuai dan cukup untuk waktu dua semester.

Kata Kunci: Analisis Buku Siswa, Kurikulum 2013, Sejarah Kebudayaan Islam

\section{PENDAHULUAN}

Indonesia kini sudah meganut sistem pendidikan nasional atau pendidikan yang berlandaskan Pancasila dan UUD 1945 serta berakar pada nilai-nilai agama, kebudayaan nasional Indonesia, dan responsif terhadap tuntutan perubahan zaman. Pendidikan harus memiliki suatu sistem guna mencapai tujuannya, salah satunya adalah dengan penerapan kurikulum. Kurikulum merupakan suatu rencana pembelajaran guna mencapai suatu tujuan lembaga pendidikan. Menurut UU No. 20 tahun 2003 tentang Sistem Pendidikan Nasional (Sisdiknas), bahwa "kurikulum adalah seperangkat rencana dan pengaturan mengenai tujuan, isi, dan bahan pelajaran serta cara yang digunakan sebagai pedoman penyelenggaraan kegiatan pembelajaran untuk mencapai tujuan pendidikan tertentu." Indonesia telah melakukan beberapa kali perubahan dalam penetapan kurikulum, kurang lebih sebanyak sebelas kali, mulai dari kurikulum 1947 (Rentjana Pelajaran 1947) hingga Kurikulum 2013 (K-13) dan perubahan tersebut disebabkan karena adanya pengembangan kurikulum. Kini hampir seluruh lembaga pendidikan menerapkan Kurikulum 2013 pada proses pembelajarannya. Kurikulum 2013 merupakan lanjutan dari hasil pengembangan Kurikulum 2004 (Kurikulum Berbasis Kompeetensi) dan KTSP 2006 yang mencakup ranah Taksonomi Bloom yaitu 
kognitif, afektif, dan psikomotorik. Tentu saja dalam penyampaian materi belajar haruslah menggunakan alat bantu, salah satunya adalah buku pegangan siswa dan buku pegangan guru yang sudah disediakan oleh pemerintah.

Tatat Hartati berpendapat, bahwa "buku ajar adalah buku yang dijadikan pegangan siswa pada jenjang tertentu sebagai media pembelajaran (instruksional) yang berkaitan dengan bidang studi." ${ }^{1}$ Buku siswa merupakan buku yang digunakan siswa sebagai panduan proses pembelajaran di kelas serta memudahkan siswa dalam menguasai materi terstentu. Jadi menurut Syamsul Arifin dan Adi Kusrianto dalam bukunya ia menyimpulkan bahwa

Buku ajar disusun sesuai dengan kebutuhan pelajar. Pertama kebutuhan akan pengetahuan, misalnya pengetahuan alam, pada siswa SD/MI kebutuhannya hanya sampai tingkatan mengetahui. Tetapi pada tingkat SMA/MA sudah harus memahami, bahkan mungkin sampai aplikasi. Di tingkat ini dibutuhkan latihan dan pendampingan. Kedua adalah kebutuhan umpan balik terhadap apa yang disampaikan kepada siswa. ${ }^{2}$

Tentu saja dalam kurikulum 2013 buku yang digunakan haruslah berbasis kurikulum 2013. Pemerintah telah menyiapkan buku siswa atau buku teks untuk semua masing-masing mata pelajaran, salah satunya adalah mata pelajaran Sejarah Kebudayaan Islam. Mata pelajaran ini hanya ditemukan pada jenjang Madrasah saja (MI, MTs, dan MA). Namun, dalam proses pengimplementasian kurikulum 2013 tidak sedikit pendidik yang masih kurang siap sehingga akan menjadi suatu masalah tersendiri. Hendaknya dalam pengimplementasian kurikulum 2013 ada beberapa aspek yang harus diperhatikan oleh para guru, antara lain metode yang diterapkan, model pembelajaran yang sesuai, materi yang disampaikan, evaluasi pembelajaran, dan lain-lain.

Dalam penyusunan buku siswa haruslah memperhatikan beberapa aspek, mulai dari kerelevansian dengan kurikulum, kesesuaian tema, ilustrasi, aspek linguistik, hingga alokasi waktu yang digunakan. Kendala dalam proses tercapainya sebuah tujuan pendidikan sangatlah bermacam-macam, baik dari pendidik maupun peserta didik.

\footnotetext{
${ }^{1}$ Binti Wasi'atul Ilmi, 2014, Analisis Buku Siswa "Pendidikan Agama Islam dan Budi Pekerti" SD Kelas I dalam Kurikulum 2013, Didaktika Religia, Vol. 2 No. 2, hal 50.

2 Syamsul Arifin \& Adi Kusrianto, Sukses Menulis Buku Ajar \& Referensi, (Jakarta: Grasindo, 2009), hal 58.
} 
Kendala yang sangat sering dijumpai terletak pada buku siswa itu sendiri, baik dalam penulisan dan ilustrasi yang kurang tepat, bahasa yang sulit dipahami, kerelevansian materi, dan sebagainya. Hal tersebut tentu saja sedikit menyalahi tujuan disusunnya buku siswa, yaitu menarik perhatian dan memotivasi siswa untuk mempelajarinya. Terutama pada siswa yang sudah memasuki usia remaja, yang mana pada usia tersebut merupakan masa transisi antara masa anak-anak dan masa dewasa. Pada usia tersebut sudah mulai terjadi banyak perubahan baik secara fisik maupun psikis. Sehingga dapat dikatakan orang yang telah memasuki usia tersebut sering muncul pertanyaan-pertanyaan yang berasal dari rasa penasarannya. Jika dkaitkan dengan dunia pendidikan, usia remaja dimulai dari kelas VII SMP/MTs. Pendidik yang baik adalah seorang pendidik yang paham akan keadaan psikologis peserta didiknya. Begitu juga dalam penyusunan buku siswa, penyusun harus memperhatikan kerelevansian dengan usia target sasaran agar materi dapat tersampaikan secara maksimal.

Dari permasalahan di atas penelitian ini bermaksud untuk melakukan beberapa kajian dengan menjawab beberapa rumusan masalah yang telah disusun, yaitu: 1) Apa saja hal yang harus diperhatikan dalam menganalisis buku siswa "Sejarah Kebudayaan Islam” kelas VII MTs dalam Kurikulum 2013? 2) Bagaimana kesesuaian konten analisis dalam buku siswa "Sejarah Kebudayaan Islam" kelas VII MTs jika dikaitkan dengan teori Psikologi?. Dengan begitu kita dapat mengetahui tentang apa saja yang harus diperhatikan dalam menganalisis dalam sebuah buku siswa. Sehingga dengan adanya analisis dapat dilakukan perbaikan kedepannya untuk buku ini.

\section{METODE}

Metode yang digunakan pada penelitian ini adalah metode library research atau biasa disebut dengan studi kepustakaan. Metode studi kepustakaan adalah serangkaian kegiatan yang berkenaan dengan metode pengumpulan data pustaka, membaca, dan mencatat serta mengolah penelitian. ${ }^{3}$ Penelitian ini menggunakan teknik pengumpulan data dengan menyajikan penelitian-penelitian terdahulu yang berkaitan. Adapun sumber kepustakaan diklasifikasikan menjadi dua, yaitu sumber primer dan sumber sekunder.

3 Abdul Hayyie Al-Kattani dan Wido Supraha, Menumbubkan Karakter Anak (Perspektif Ibn Abd Al-Barr AlAndalusi, (Yogyakarta: Penerbit Deepublish, 2018), hal 16. 
Sumber primer merupakan karangan asli yang ditulis oleh seorang yang melihat, mengalami atau mengerjakan sendiri, seperti buku harian (autobiography), tesis, disertasi, laporan penelitian, hasil wawancara, laporan statistik, dan sebagainya. Ssedangkan sumber sekunder merupakan tulisan tentang penelitian orang lain, tinjauan, ringkasan, kritikan, dan tulisan-tulisan serupa mengenai hal-hal yang tidak langsung disaksikan atau dialami sendiri oleh penulis, seperti ensiklopedi, kamus, buku pegangan, abstrak, indeks, dan textbooks. ${ }^{4}$

\section{HASIL DAN PEMBAHASAN}

Binti Wasiatul Ilmi dalam penelitiannya pada tahun 2014 yang berjudul "Analisis Buku Siswa "Pendidikan Agama Islam dan Budi Pekerti" SD Kelas 1 dalam Kurikkulum 2013", berpendapat bahwa kesesuaian materi dengan tema dalam buku siswa PAI dan Budi Pekerti SD Kelas I dilihat dari kesesuaian materi dengan kurikulum, $\mathrm{KI}$ dan KD, tujuan, serta kesesuaian materi dengan isi kolom buku siswa. ${ }^{5}$ Menurut Abdur Rokhman Wakhid melalui penelitiannya pada tahun 2017 yang berjudul "Analisis Buku Siswa Sejarah Kebudayaan Islam kelas X” untuk Tugas Akhir Skripsi (S1) UIN Maulana Malik Ibrahim Malang bahwa: 1) Akurasi materi pada buku siswa Sejarah Kebudayaan Islam Kelas X yang diterbitkan oleh Depag RI memiliki 5 unsur akurasi, yaitu a) akurasi konsep pada buku, terdapat 5 pokok bahasan yang belum akurat, b) akurasi prinsip pada buku terdapat 1 bahasan yang belum akurat, c) akurasi prosedur terdapat 4 pokok bahasan yang sudah sistematis, d) akurasi contoh, fakta, dan ilustrasi pada buku tersebut sudah akurat, e) akurasi soal pada buku tersebut belum cukup untuk melatih kemampuan siswa dalam memahami materi. Sajian pada buku siswa SKI Kelas $\mathrm{X}$ in memiliki 8 unsur kelayakan, yaitu konsistensi sistematika sajian,, penulisan ayat AlQuran dan hadits, kata pengantar, glosarium, daftar pustaka, rangkuman, daftar indeks, serta keterlibatan peserta didik. ${ }^{6}$ Menurut Siti Khoiriyah dalam penelitiannya pada tahun 2016 yang berjudul "Analisis Isi Buku Teks Pendidikan Agama Islam dan Budi Pekerti SMP Kelas VII” untuk Tugas Akhir Skripsi (S1) bahwa materi yang disajikan pada Buku

\footnotetext{
${ }^{4}$ I Made Indra \& Ika Cahyaningrum, Cara Mudah Memahami Metodologi Penelitian, (Yogyakarta: Penerbit Deepublish, 2019), hal 28

${ }^{5}$ Binti Wasi'atul Ilmi, Op.Cit.,hal 67.

6 Abdur Rokhman Wakhid, “Analisis Buku Siswa Sejarah Kebudayaan Islam Kelas X." (Skripsi UIN Maulana Malik Ibrahim Malang, Malang: 2017), hal 83.
} 
Teks PAI dan Budi Pekerti SMP Kelas VII jika ditinjau dari perspektif psikologi peserta didik dimensi biologis sudah sesuai dengan tingkat perkembangan peseta didik. Jika ditinjau dari perspektif psikologi peserta didik dimensi kognitif, materi yang disajikan sudah sesuai dengan psikologi perkembangan pada tahap kognitif remaja. Serta jika ditinjau dari perspektif psikologi perkembangan dimensi sosio-emosional materi yang disajikan juga sudah sesuai, yaitu menjadikan pendidikan sebagai tempat pengembangan keterampilan sosial dan kepribadian peserta didik. ${ }^{7}$ Menurut Rifatul Mahmudah dalam penelitianny pada tahun 2016 yang berjudul “Analisis Kualitas Buku Teks Pelajaran Pendidikan Agama Islam dan Budi Pekerti Kelas VII Sekolah Menengah Pertama (SMP) Kurikulum 2013 di Kabupaten Malang” untuk Tugas Akhir Tesis (S2), bahwa buku teks pelajaran Pendidikan Agama Islam yang berkualitas adalah buku teks yang materi dan penyajiannya sesuai dengan kurikulum berlaku, sesuai dengan karakteristik mata pelajaran PAI, dan sesuai dengan karakteristik pserta didik. Dalam hal isi sebaiknya ada materi agama yang diintegrasikan dengan sains. ${ }^{8}$

Dalam menganalisis sebuah buku ada beberapa aspek yang harus diperhatikan oleh penganalisis. Buku teks yang baik adalah buku yang relevan serta menunjang pelaksanaan kurikulum. Kualitas suatu buku dapat dilihat dari sudut pandang, kejelasan konsep, kerelevansian dengan kurikulum, menarik minat siswa, menumbuhkan motivasi, menstimulasi aktivitas siswa, ilustratif, mudah dipahami oleh siswa, menunjang mata pelajaran lain, menghargai perbedaan individu, serta menyajikan nilai-nilai yang dapat diambil. Sebelum menganalisis lebih dalam buku siswa "Sejarah Kebudayaan Islam" kelas VII MTs dalam kurikulum 2013, peneliti akan memaparkan sedikit identitas buku ini. Buku siswa yang berjudul "Sejarah Kebudayaan Islam Kelas VII MTs" ini sebuah buku yang diterbitkan oleh Kementrian Agama Republik Indonesia pada tahun 2014 (cetakan pertama) dengan nomor ISBN 978-979-8446-75-7.

\footnotetext{
7 Siti Khoiriyah, "Analisis Isi Buku Teks Pendidikan Agama Islam dan Budi Pekerti SMP Kelas VII", (Skripsi UIN Sunan Kalijaga Yogyakarta, Yogyakarta: 2016), hal 128.

${ }^{8}$ Rifatul Mahmudah, "Analisis Kualitas Buku Teks Pelajaran Pendidikan Agama Islam dan Budi Pekerti Kelas VII Sekolah Menengah Pertama (SMP) Kurikulum 2013 di Kabupaten Malang”, (Tesis UIN Maulana Malik Ibrahim Malang, Malang: 2016), hal 174.
} 


\section{Kesesuaian Materi dengan Kurikulum dan Kejelasan Konsep}

Kurikulum 2013 dikembangkan atas teori standard-based education (pendidikan berdasarkan standar) dan competency-based curriculum (kurikulum berbasis kompetensi). Kerelevansian kurikulum dapat dilihat dari rincian Kompetensi Inti (KI) dan Kompetensi Dasar (KD). Buku ini sudah relevan dengan kurikulum yang ada yaitu Kurikulum 2013. Dikatakan sudah relevan karena isi dari Kompetensi Inti (KI) dan Kompetensi Dasar (KD) dari buku ini sudah sangat sesuai dengan Permenag No. 912 tahun 2013. Setiap KI dan KD yang dicantumkan haruslah mengarah pada ranah afektif, kognitif, dan psikomotorik. Sedangkan untuk kejelasan konsep menurut Tarigan dalam Telaah Buku Bahasa Indonesia, "konsep-konsep yang digunakan dalam suatu buku teks harus jelas dan tandas." Untuk kejelasan konsep, buku ini menyajikan peta konsep di setiap permulaan bab. Sehingga memudahkan pembaca untuk mendapatkan gambaran umum tentang materi yang akan dibahas. Peta konsep yang disajikan pada buku ini cukup jelas dan mudah untuk dipahami.

\section{Isi Materi}

Materi pembelajaran adalah materi yang digunakan untuk mencapai tujuan pembelajaran. Sedangkan menurut Wina Sanjaya, sebagai berikut

Bahan atau materi pelajaran (learning materials) adalah segala sesuatu yang menjadi isi kurikulum yang harus dikuasai oleh siswa sesuai dengan kompetensi dasar dalam rangka pencapaian standar kompetensi setiap mata pelajaran dalam satuan pendidikan tertentu. Materi pelajaran merupakan bagian terpenting dalam proses pembelajaran, bahkan dalam pengajaran yang berpusat pada materi pelajaran (subject-centered teaching), materi pelajaran merupakan inti dari kegiatan pembelajaran. Menurut subject centered teaching, keberhasilan suatu proses pembelajaran ditentukan oleh seberapa banyak siswa dapat menguasai materi kurikulum. ${ }^{9}$

Materi pembelajaran diklasifikasikan menjadi beberapa aspek, antara lain pengetahuan (knowledge), sikap (attitude), dan keterampilan (skill). Materi pada buku ini adalah materi tentang Sejarah Kebudayaan Islam (SKI). SKI merupakan salah satu mata pelajaran yang terhimpun dalam PAI serta mata pelajaran yang menanamkan pendidikan tentang

${ }^{9}$ Wina Sanjaya, Perencanaan dan Desain SIstem Pembelajaran, (Jakarta: Kencana, 2008), hal. 141-142. 
perjalanan dan perkembangan budaya umat Islam yang pada umumnya para pendidik menggunakan metode ceramah dalam penyampaiannya. Adapun beberapa karakteristik dari mata pelajaran ini, antara lain menekankan kemampuan dalam pengambilan ibrah atau nilai dari sejarah Islam, bersifat kronologis, serta sejarah mengandung prisnsip sebab-akibat.

Buku teks atau buku siswa yang baik menurut Awalludin dalam Pengembangan Buku Teks Sintaksis Bahasa Indonesia, bahwa "isi materi harus dikembangkan berdasarkan konsep dan teori yang relevan serta harus bersifat valid, serta harus mudah dipahami oleh siswa. ${ }^{10}$ Jika dilihat dari teori di atas, isi materi yang disajikan dalam buku ini sudah sesuai dengan yang tertulis pada KI dan KD. Buku ini memuat 5 bab. Bab pertama, tentang keadaan masyarakat Mekkah hinggan pola dakwah Rasulullah saw. Bab kedua, tentang kondisi masyarakat Madinnah sebelum hijrah responnya terhadap dakwah Rasulullah saw. Bab ketiga, tentang Khulafaurrasyidin. Bab keempat membahas tentang kekhalifahan Bani Umayyah. Dan terakhir bab kelima, tentang pengembangan kebudayaan Islam. Sungguh disayangkan, pada buku ini tidak ada pengklasifikasian mengenai materi semester ganjil dan genap, sehingga akan membuat peserta didik sedikit mengalami kebingungan, sehingga buku ini kurang sempurna. Untuk kedalaman dan keluasan materi yang disajikan sudah cukup sesuai dengan kemampuan kognitif usia remaja yaitu adanya peningkatan dalam kemampuan kogntifnya. Sebagaimana yang dikemukakan oleh John W. Santrock:

"Perubahan kognitif yang memungkinkan peningkatan berpikir kritis di masa remaja dapat mencakup: peningkatan kecepatan dalam memproses informasi, isi pengetahuan yang lebih luas, peningkatan dalam mengkonstruksikan hal baru dari pengetahuan, serta perluasan strategi dalam mengaplikasikan pengetahuan." 11

Di dalam buku tersebut terdapat beberapa komponen yang mampu membantu peserta didik dalam memahaminya, yaitu pada setiap bab pasti menyajikan kolom "manfaat, "wawasan", "lembar latihan mandiri", "lembar tugas kelompok", "ibrah", dan juga kolom "rangkuman." Akan tetapi dalam buku ini tidak diklasifikasikan antara semester

${ }_{10}$ Awalludin, Pengembangan Buku Ajar Sintaksis Bahasa Indonesia, (Yogyakarta: Penerbit Deepublish, 2017), hal 16.

${ }^{11}$ John W. Santrock, Liffe-Span Development: Perkembangan Masa Hidup Edisi Ketigabelas Jilid 1, Jakarta: Penerbit Erlangga, 2012), hal. 425. 
ganjil dan semester genap, sehingga siswa akan sedikit lebih sulit dalam menentukannya. Untuk kedalaman dan keluasan materi yang disajikan sudah cukup luas sesuai dengan kemampuan kognitif usia remaja dimana sudah mulai ada peningkatan. Sebagaimana yang dikemukakan oleh John W. Santrock:

"Perubahan kognitif yang memungkinkan peningkatan berpikir kritis di masa remaja dapat mencakup: peningkatan kecepatan dalam memproses informasi, isi pengetahuan yang lebih luas, peningkatan dalam mengkonstruksikan hal baru dari pengetahuan, serta perluasan strategi dalam mengaplikasikan pengetahuan." 12

\section{Ilustrasi dan Aspek Kebahasaan}

Ilustrasi merupakan suatu gambar atau foto yang digunakan untuk menjelaskan suatu naskah atau teks/tulisan. ${ }^{13}$ Fungsi dari ilustrasi itu sendiri adalah sebagai penjelas dari bacaan sehingga mudah dipahami oleh pembaca. Tentu saja buku yang baik akan menampilkan ilustrasi yang tepat, baik dengan tema maupun peserta didik. Ilustrasi atau gambar yang ditampilkan masih kurang tepat karena pada buku ini jarang sekali menampilkan ilustrasi. Ilustrasi hanya ditampilkan pada bagian cover dan halamanhalaman tertentu saja. Hal ini dapat mengakibatkan peserta didik atau pembaca enggan dan mudah bosan untuk membaca buku ini dikarenakan keterbatasan ilustrasi yang ditampilkan. Alangkah lebih baik buku ini menampilkan ilustrasi pada setiap bab guna menimbulkan rasa penasaran pembaca dan mampu menghadirkan imajinasi dalam membaca mengingat mata pelajaran ini membahas tentang masa lampau. Sebagaimana teori kognitif Piaget, yaitu

"Dalam tahap operasional formal, sebagai tahap keempat dari perkembangan kognitif menurut Piaget, pemikiran individu menjadi lebih abstrak, idealis, dan logis, dibandingkan di tahap operasional konkret. Remaja menjadi lebih mampu bernalar secara hipotesis-deduktif. Meskipun demikian, banyak remaja yang bukan pemikir operasional formal maupun berusaha mengonsolidasikan pemikiran operasional konkretnya." 14

\footnotetext{
12 Ibid., hal 425.

${ }^{13}$ Margono, dkk., Pelajaran Seni Budaya 1: Seni Rupa \& Seni Teater Kelas X, (Jakarta: Yudhistira, 2007), hal 7. ${ }^{14}$ John W. Santrock, Op. Cit., hal 423.
} 
Dengan teori tersebut, dapat dikembangkan bahwa salah satu cara agar siswa mampu menalar secara hipotesis-deduktif adalah dengan menampilkan ilustrasi yang menarik. Untuk desain cover cukup menarik, akan tetapi desainya terlalu ramai, sehingga sulit untuk dipahami.

Pada aspek kebahasan, bahasa yang digunakan dalam buku ini sudah cukup lugas, efektif, komunikatif, dialogis, dan interaktif. Dalam buku ini juga disediakan kolom "Glosarium" sehingga mempermudah siswa dalam mencari kata-kata yang sulit. Akan tetapi masih ada beberapa ketidaksempurnaan dalam segi penulisan maupun ejaan dan tidak sesuai dengan kaidah Ejaan Yang Disempurnakan (EYD). Ada beberapa pengulangan kata dalam satu kalimat yang mengakibatkan pemborosan kata serta ada beberapa istilah yang tidak dicetak miring, serta ada beberapa istilah yang sulit untuk dipahami, Menurut Kuhn (2009) "Kognitif terpenting yang berlangsung pada remaja adalah peningkatan di dalam fungsi eksekutif, yang melibatkan kognitif dalam tingkat yang lebih tinggi." "15 Melihat teori yang dikemukakan oleh Kuhn, dengan adanya beberapa istilah yang sangat asing bagi usia remaja, hal tersebut tidak berpengaruh banyak dalam proses penyerapan informasi. Karena dengan adanya istilah asing tersebut, siswa dapat memperluas penalaran mereka.

\section{Ibrah dan Alokasi Waktu}

Ibrah berasal dari kata 'abra' yang berarti pengertian, teladan, pelajaran, heran, dan melihat keadaan. ${ }^{16}$ Dalam penyusunan buku teks penulis harus menyajikan kolom ibrah, agar pembaca lebih mudah untuk mengambil ibrah yang kemudian dapat diimplementasikan dalam kehidupan sehari-hari. Banyak sekali ibrah yang dapat dipetik dari buku ini, mulai dari akhlak Rasulullah hingga cara kepemimpinan yang adil dalam suatu negara. Untuk mempermudah siswa dalam mengetahui ibrah, buku tersebut menyajikan kolom "Mutiara Hikmah". Serta ada beberapa kisah yang mampu menumbuhkan motivasi siswa, siswa diajarkan agar mampu menghargai perbedaan individu, serta mampu memantapkan nilai-nilai Islam dalam kehidupan sehari-hari. Hal

\footnotetext{
15 Ibid., hal 425.

${ }^{16}$ Kaharuddin, Mencetak Generasi Anak Shaleh dalam Hadits, (Yogyakarta: Penerbit Deepublish, 2018), hal 138.
} 
tersebut tentu saja menghindari terjadi kesalahpahaman peserta didik dalm menyimpulkan sebuah materi, karena pada usia ini peserta didik sudah mampu menyimpulkan sesuatu. Sebagaimana dalam teori perkembangan Piaget, Berk (2003: 244-249) bahwa perkembangan kognitif pada masa ini memiliki ciri-ciri, salah satunya adalah mampu menalar secara abstrak dalam situasi yang menawarkan beberapa kesempatan untuk melakukan penalaran deduktif hipotesis dan berpikir proporsisional, yaitu pada masa ini sudah mampu untuk menyimpulkan sesuatu dalam suatu hipotesis (prediksi). ${ }^{17}$

Alokasi waktu yang digunakan untuk mata pelajaran SKI adalah 40 menit per jam. Untuk materi yang dirasa lebih sulit, maka durasi yang diberikan lebih banyak. Jadi semakin sulit suatu materi, maka semakin banyak pula durasi yang diberikan. Sedangkan untuk materi yang dianggap mudah, alangkah baiknya menyediakan durasi yang tidak terlalu banyak. Hal tersebut sesuai dengan pendapat Mulyasa, bahwa "Pada setiap kompetensi dasar dilakukan dengan memperhatikan jumlah minggu efektif dan alokasi mata pelajaran perminggu dengan mempertimbangkan jumlah KD, keluasan, tingkat kesulitan, dan tingkat kepentingannya." Jika ditinjau dalam aspek psikologi usia MTs kelas VII (13 tahun) dalam teori Piaget tergolong pada tahap operasional formal, bahwa "Karakteristik tahap ini ialah diperolehnya kemampuan untuk berpikir secara abstrak, menalar secara logis, dan menarik kesimpulan dari informasi yang tersedia." ${ }^{18}$ Sehingga alokasi waktu pada buku ini dapat dikatakan sudah sesuai dan cukup untuk digunakan oleh siswa kelas VII MTs dalam jangka waktu satu tahun (dua semester).

\section{KESIMPULAN}

Dengan demikian berdasarkan analisis yang telah peneliti lakukan terhadap buku Sejarah Kebudayaan Islan kelas VII MTs dengan Kurikulum 2013, bahwa ada beberapa hal yang harus diperhatikan dalam menganalisis sebuah buku, yaitu: kerelevansian dengan kurikukulum, kejelasan konsep, isi materi, ilustrasi, aspek kebahasaan, ibrah, serta alokasi waktu. Adapun hasil analisis buku siswa Sejarah Kebudayaan Islam kelas VII MTs dengan Kurikulum 2013, sebagai berikut: 1)

17 Herlina, Bibliotherapy: Mengatasi Masalah Anak dan Remaja melalui Buku, (Bandung: Pustaka Cendekia Utama, 2013).

18 Yudrik Jahja, Psikologi Perkembangan Edisi Pertama, (Jakarta: Kencana, 2011), hal 118. 
Kerelevansian dengan kurikulum, KI dan KD yang disusun sudah relavan dengan kurikulum 2013 karena sudah sangat sesuai dengan Permenag No. 912 tahun 2013. 2) Kejelasan konsep pada buku SKI Kelas VII MTs Kurikulum 2013 ini sudah cukup jelas dan mudah dipahami dengan menyajikan peta konsep di setiap permulaan bab, 3) Isi materi jika ditinjau dari segi psikologi, kedalaman dan keluasan materi sudah sesuai dengan usia peserta didik, yitu usia remaja, 4) Ilustrasi, untuk penyajian ilustrasi jika ditinjau dari segi psikologi masih kurang tepat dalam penempatannya dan masih ada beberapa gambar yang kurang sesuai dengan tema, seperti cover, 5) Aspek Kebahasaan, bahasa yang digunakan pada buku ini cukup lugas, efektif, komunikatif, dialogis, dan interaktif. Jika dikaitkan dengan segi psikologis, bahasa yang disajikan sudah sesuai dengan kondisi psikis usia remaja, yaitu mulai melibatkan kemampuan kognitif, 6) Ibrah pada buku ini dapat dilihat pada kolom "Mutiara Hikmah" pada setiap bab, dan itu sangat memudahkan pembaca, 7) Alokasi waktu, alokasi waktu yang disediakan 40 menit per jam. Ukuran ini sudah sesuai dengan peserta didik jika dilihat dari keadaan psikologi remaja yang sudah mampu menangkap informasi yang tersedia.

Dari hasil temuan analisis di atas, peneliti akan memberikan beberapa saran kepada beberapa pihak terutama penulis dengan harapan dapat dijadikan referensi sebagai bahan evaluasi untuk perbaikan buku siswa selanjutnya, antara lain: 1) Terkait isi materi, seharusnya buku siswa ini terdapat pengklasifikasian antara materi semester ganjil dan materi semester genap untuk menghindari kebingungan peserta didik, 2) Ilustrasi yang ditampilkan hendaknya lebih menarik minat pembaca, baik dalam segi penempatannya maupun desainnya, 3) Aspek kebahasaan masih perlu banyak perbaikan agar tidak lagi terjadi kesalahan baik dalam penulisan maupun pengulangan kata yang mengakibatkan kalimat tersebut sulit untuk dipahami, 4) Buku akan lebih baik jika disajikan beberapa analogi permasalahan, agar peserta didik dapat berpikir kritis. Sebagaimana dalam buku Psikologi Perkembangan yang ditulis oleh Yudrik Jahja, bahwa pada usia remaja mereka mampu menarik kesimpulan analogi. ${ }^{19}$

${ }^{19}$ Ibid., hal 54. 


\section{DAFTAR PUSTAKA}

Kementerian Agama. 2014. Sejarah Kebudayaan Islam Pendekatan Saintifik Kurikulum 2013 untuk Madrasah Tsanawiyah Kelas VII. Jakarta: Kementrian Agama Republik Indonesia.

Menteri Agama Republik Indonesia. 2013. Peraturan Menteri Agama Republik Indonesia Nomor 000912 tabun 2013 Tentang Kurikulum Madrasah 2013 Mata Pelajaran Pendidikan Agama Islam dsn Bahasa Arab. Jakarta: Menteri Agama Republik Indonesia.

Tim Dosen FAI UMM. 2019. Pedoman Penulisan Tugas Akhir \& Berita Acara Bimbingan. Malang: Fakultas Agama Islam Universitas Muhammadiyah Malang.

Arifin, Syamsul \& Adi Kusrianto. 2009. Sukses Menulis Buku Ajar \& Referemsi. Jakarta: Grasindo

Awalludin. 2017. Pengembangan Buku Ajar Sintaksis Bahasa Indonesia. Yogyakarta: Penerbit Deepublish.

Herlina. 2013. Bibliotherapy: Mengatasi Masalab Anak dan Remaja Melalui Buku. Bandung: Pustaka Cendekia Utama.

Ilmi, Binti Wasi'atul. 2013. Analisis Buku Siswa "Pendidikan Agama Islam dan Budi Pekerti” SD Kelas I dalam Kurikulum 2013. Didaktika Religia 2(2). 45-70.

Indra, I Made \& Ika Cahyaningrum. 2019. Cara Mudah Memahami Metodologi Penelitian. Yogyakarta: Penerbit Deepublish.

Jahja, Yudrik. 2011. Psikologi Perkembangan Edisi Pertama. Jakarta: Kencana.

Kaharuddin. 2018. Mencetak Generas Anak Sholeh dalam Hadits. Yogyakarta: Penerbit Deepublish.

Kattani, Abdul Hayyie Al \& Wido Supraha. 2018. Menumbubkan Karakter Anak (Perspektif Ibn Abd Al-Barr Al-Andalusi. Yogyakarta: Penerbit Deepublish.

Khoiriyah, Siti. 2016. Analisis Isi Buku Teks Pendidikan Agama Islam dan Budi Pekerti SMP Kelas VII. Skripsi Fakultas Ilmu Tarbiyah dan Keguruan Universitas Islam Negeri (UIN) Sunan Kalijaga, Yogyakarta 2016.

Mahmudah, Rifatul. 2016. Analisis Kualitasa Buku Teks Pelajaran Pendidikan Agama Islam dan Budi Pekerti Kelas VII Sekolah Menengah Pertama (SMP) Kurikulum 2013 di Kabupaten Malang. Tesis Program Megister Pendidikan Agama Islam Universitas Islam Negeri (UIN) Maulana Malik Ibrahim, Malang 2016.

Margono, dkk. 2007. Pelajaran Seni Budaya 1: Seni Rupa \& Seni Teater Kelas X. Jakarta: Yudhistira.

Prastowo, Andi. 2015. Menyusun Rencana Pelaksanaan Pembelajaran (RPP) Tematik Terpadu Implementasi Kurikulum 2013 untuk SD/MI. Jakarta: Kencana.

Sanjaya, Wina. 2018. Perencanaan dan Desain Sistem Pembelajaran. Jakarta: Kencana.

Santrock, John W. 2012. Life-Span Development: Perkembangan Masa Hidup Edisi Ketigabelas Jilid I. Jakarta: Penerbit Erlangga. 
Irinne Fauz Yusria

Wakhid, Abdur Rokhman. 2017. Analisis Buku Siswa Sejarah Kebudayaan Islam Kelas X. Skripsi Fakultas Ilmu Tarbiyah dan Keguruan Universitas Islam Negeri (UIN) Maulana Malik Ibrahim, Malang 2017.

Yunus, Hamzah. 2015. Perencanaan Pembelajaran Berbasis Kurikulum 2013. Yogyakarta: Penerbit Deepublish. 